\title{
PENGGUNAAN MEDIA MASSA SEBAGAI AGEN SOSIALISASI DINAS KESEHATAN KABUPATEN TASIKMALAYA DALAM MENINGKATKAN KESADARAN MASYARAKAT AKAN PENTINGNYA IMUNISASI
}

\author{
Kokom Komariah, Priyo Subekti \\ Fakultas Ilmu Komunikasi, Universitas Padjadjaran \\ E-mail: kokomkomariah.humas@gmail.com
}

\begin{abstract}
ABSTRAK
Penelitian ini berjudul Penggunaan Media Massa Sebagai Agen Sosialisasi Dinas Kesehatan Kabupaten Tasikmalaya dalam meningkatkan Kesadaran Masyarakat akan pentingnya Imunisasi. Penelitian ini bertujuan untuk mengetahui: 1) media yang digunakan dalam upaya sosialiasi kepada masyarakat tentang pentingnya imunisasi pasca isu vaksin mengandung Tripsin; 2) hambatan yang di hadapai Dinas Kesehatan Kabupaten Tasikmalaya dalam upaya sosiliasi kepada masyarakat tentang pentingnya imunisasi pasca isu vaksin mengandung Tripsin. Metode yang digunakan adalah metode deskriptif dengan data kualitatif. Lokasi penelitian di Dinas Kesehatan Kabupaten Tasikmalaya.

Hasil penelitian menunjukkan: 1) Media yang digunakan dalam upaya sosialiasi kepada masyarakat tentang pentingnya imunisasi pasca isu vaksin mengandung Tripsin yaitu secara nasional dari pemerintah melalui media massa (televisi, radio), media sosial (twitter, facebook), serta media nir-massa (spanduk, pamflet, baligo, brosur, CD). Secara khususnya Pemkab. Tasikmalaya untuk media massanya melalui radio swasta (2 radio swasta yang ada di kota tasikmalaya yaitu Talk show), media nir-massa (spanduk, baligo, umbulumbul, balon, kaos), serta media sosial (twitter, WA, bbm); 2) Hambatan-hambatan yang dihadapi Dinkes Kab. Tasikmalaya dalam sosialisasi dan pelaksanaan PIN polio 2016 : a) Biaya sosialisasi dan pelaksanaan Program Imunisasi Nasional (PIN) Polio ini adalah dari APBN, APBD melalui BOK (bantuan operasional kesehatan) th 2016. Akan tetapi karena pelaksanaan PIN 2016 ini jatuh di bulan Maret, anggaran dana tersebut belum 'turun', oleh karena itu semua dana adalah dana talangan dan utang; b) Terbatasnya petugas Dinkes; c) Kondisi ada lokasi masyarakat jauh dan susah dijangkau kendaraan bermotor, sehingga pada pelaksanaan PIN memakan waktu 3 hari dan ada yang dilaksanakan sore hari; d) Tempat membawa vaksin (termos vaksin) standar internasional yang dimiliki Dinkes dan Puskesmas kurang jumlahnya, sementara harganya mahal dan anggaran belum turun.
\end{abstract}

Kata kunci: Vaksin, imunisasi, media sosialisasi, agen sosialisasi

\section{IMPLEMENTATION OF MASS MEDIA AS SOCIALIZATION AGENT FOR HEALTH OFFICE OF TASIKMALAYA REGENCY IN INCREASING PUBLIC AWARANESS ON IMMUNISATION}

\begin{abstract}
Research entitled "Implementation of Mass Media as Socialization Agent for Health Office of Tasikmalaya Regency in Increasing Public Awaraness on Immunisation". The purpose of this research are to explore: 1) the media utilization in immunisation socialization towards the public on the importance of immunisation after the issue of vaccine containing tripsin; 2) the obstacles confronted by Health Office of Tasikmalaya Regency in the socialization towards the public on the importance of immunisation after the issue of vaccine containing tripsin. The method applied for this research is descriptive method with qualitative data. The location for this research is at Health Office of Tasikmalaya Regency.

The result of this reseach shows that: 1) Media used for the national socialization from the government includes: mass media (Television and Radio), Social Media (Twitter, Facebook), and non-mass media (Banner, Billboard, Brochure, CD). While Tasikmalaya Regency Government utilizes: mass media through talk-show in two private radios, non-mass media (using Banner, Billboard, Balloon, and T-Shirt), and social media (using twitter, Whatsapp, and BBM); 2) the obstacles confronted by Health Office of Tasikmalaya Regency in the PIN Polio 2016 socialization are as follows: a) cost of socialization for PIN (stands for Program Imunisasi Nasional or National Immunisation Program) is coming from national budget and regional budget through BOK (stands for Bantuan Operasional Kesehatan or Health Operational Aid) of 2016; As the implementation of PIN 2016 was held in March, the funding from both national and regional budget was not yet available, and putting the implementation fund source from lending fund; b) The limited
\end{abstract}


number of Health Office staffs; c) the remote location, unreachable by motorized vehicle, which took PIN implementation 3 days to be completed, with some of them was held in the late afternoon; d) Limited number of expensive vaccine thermos with international standard owned by Health Office, with a restricted budget as it is not yet available, Health Office would not be able to purchase new units.

Keywords: Vaccine, Immunisation, Socialization media, Socialization agent

\section{PENDAHULUAN}

Permasalahan kesehatan tahun 2012 khususnya terdapat pada bidang imunisasi dasar lengkap yang termasuk didalam penyakit menular yang dapat dicegah dengan imunisasi (PD3I) harus mendapat perhatian lebih oleh banyak pihak. Beberapa diantaranya penyakit Campak, Difteri, Pertusis, Tetanus Neonatorum, Tuberkolosis, Hepatitis B dan Polio. Apabila penyakit menular ini tidak segera dilakukan pencegahan dengan pemberian imunisasi lengkap, maka akan menyebabkan kematian ataupun kecacatan pada penderita.

Bayi balita tidak di imunisasi akan terjadi wabah, sakit berat, kematian atau cacat. Contohnya wabah wabah polio tahun 20052006 dari Sukabumi menjalar ke Banten, Lampung, Jawa Timur, Jawa Tengah dalam waktu beberapa bulan menyebabkan 351 balita lumpuh seumur hidup. Wabah campak 20082010 diberbagai daerah menyebabkan 5818 anak dirawat di rumah sakit, 16 meninggal. Wabah difteri di Jawa Timur tahun 2005 2012 menjalar ke Kalimantan menyebabkan 1789 anak dirawat di rumah sakit, lebih dari 94 meninggal dunia. ${ }^{1}$

Dengan imunisasi yang lengkap dan teratur akan timbul kekebalan spesifik yang mampu mencegah penularan, wabah, sakit berat, cacat atau kematian akibat penyakitpenyakit tersebut. Setelah diimunisasi lengkap masih bisa tertular penyakit-penyakit tersebut, tetapi jauh lebih ringan dan tidak berbahaya, dan jarang menularkan pada bayi-balita lain sehingga tidak terjadi wabah.

Program imunisasi dasar, Lima Imunisasi dasar Lengkap (LIL), yang dicanangkan oleh pemerintah bagi bayi meliputi 1 dosis BCG, 3 dosis DPT, 4 dosis Polio, 4 dosis Hepatitis B dan 1 dosis Campak (Depkes, 2010). Namun pada kenyataannya program imunisasi dasar lengkap yang telah dilakukan tidak seluruhnya berhasil dan masih banyak bayi atau balita 1 http://www.rscm.co.id/index.php?option=com_content\&view=article $\& \mathrm{id}=112$ :pentingnya-imunisasi\&catid=85:rscm-news $\&$ Itemi $\mathrm{d}=435$ \&lang=id diakses tgl 30 Maret 2016 status kelengkapan imunisasinya belum lengkap, banyak faktor yang menyebabkan kelengkapan imunisasi, faktor tersebut antara lainsikap petugas, lokasi imunisasi, kehadiran petugas, usia ibu, tingkat pendidikan ibu, tingkat pendapatan keluarga per bulan, kepercayaan terhadap dampak buruk pemberian imunisasi, status pekerjaan ibu, tradisi keluarga, tingkat pengetahuan ibu, dan dukungan keluarga.

Dinas Kesehatan Tasikmalaya sendiri sudah melakukan sosialisasi mengenai vaksin dan tripsin dengan mengundang pembicara kredibel dari biofarma, juga telah mengundang pihak tokoh masyarakat, MUI, dan LSM setempat tetapi tidak membuahkan hasil. Karena ada beberapa pihak yang tetap menganggap vaksin yang mengandung tripsin itu haram, meskipun MUI sendiri tidak mengeluarkan fatwa haram, tetapi juga tidak mengeluarkan fatwa halal.

Sosialiasi mengenai PIN (Pekan Imunisasi Nasional) yang dilakukan oleh Dinas Kesehatan Kabupaten Tasikmalaya, menggunakan berbagai media mulai media massa (televisi, radio komunitas, dan media cetak) serta menggunakan media nirmassa yaitu pamflet, spanduk, baligo dll, tetapi masih tetap ada masyrakat yang menolak imuniasi dengan alasan keyakinan.

Di samping sosialisasi, untuk menyukseskan program tersebut, Dinas Kesehatan Kabupaten Tasikmalaya telah menyiapkan Pos PIN yang terletak di Puskesmas, Posyandu, Polindes, Pustu, Klinik Swasta, Rumah Sakit dan tempat-tempat umum lainnya dengan tenaga 3-4 orang kader pada setiap pos nya.

Dinas Kesehatan Kabupaten Tasikmalaya juga akan melakukan pergantian vaksin trivalent Oral Polio Vaccine (tOPV) ke bivalent Oral Polio Vaccine (bOPV) dan introduksi Inactivated Polio Vaccine (IPV), sebagai standar nasional, yang rencananya akan dilakukan pada Bulan Juli 2016. Pelaksanaan teknisnya, bayi yang berumur 4-11 bulan akan mendapatkan suntikan vaksin polio satu kali pada jadwal imunisasi rutin. 
Berdasarkan fenomena di atas maka dirumuskan pertanyaan penelitian sebagai berikut:

1. Apa media yang digunakan dalam upaya sosialiasi kepada masyarakat tentang pentingnya imunisasi pasca isu vaksin mengandung Tripsin?

2. Apa hambatan yang di hadapai Dinas Kesehatan Kabupaten Tasikmalaya dalam upaya sosiliasi kepada masyarakat tentang pentingnya imunisasi pasca isu vaksin mengandung Tripsin?

\section{Definisi Imunisasi}

Imunisasi dasar adalah pemberian imunisasi awal pada bayi yang baru lahir sampai usia satu tahun untuk mencapai kadar kekebalan diatas ambang perlindungan. (Depkes RI, 2010). Secara khusus, antigen merupakan bagian protein kuman atau racun yang jika masuk ke dalam tubuh manusia, maka sebagai reaksinya tubuh harus memiliki zat anti. Bila antigen itu kuman, zat anti yang dibuat tubuh manusia disebut antibody. Zat anti terhadap racun kuman disebut antitoksin.

Pemberian imunisasi memberikan manfaat sebagai berikut :

1. Untuk anak, bermanfaat mencegah penderitaan yang disebabkan oleh penyakit menular yang sering berjangkit;

2. Untuk keluarga, bermanfaat menghilangkan kecemasan serta biaya pengobatan jika anak sakit;

3. Untuk negara, bermanfaat memperbaiki derajat kesehatan, menciptakan bangsa yang kuat dan berakal untuk melanjutkan pembangunan negara (Depkes RI, 2010).

\section{Sosialiasi}

Sosialisasi adalah sebuah proses penanaman atau transfer kebiasaan atau nilai dan aturan dari satu generasi ke generasi lainnya dalam sebuah kelompok atau masyarakat. Sejumlah sosiolog menyebut sosialisasi sebagai teori mengenai peranan (role theory). Karena dalam proses sosialisasi diajarkan peran-peran yang harus dijalankan oleh individu (wikipedia, 2016).

Proses sosialisasi tidak bisa dipisahkan dengan peran agen agen sosialisasi. Menurut Fuller dan Jacobs (1973) dalam Sunarto (2004), Agen sosialisasi adalah pihak-pihak yang melaksanakan atau melakukan sosialisasi. Ada empat agen sosialisasi yang utama, yaitu keluarga, kelompok bermain, media massa, dan lembaga pendidikan sekolah. Pesan-pesan yang disampaikan agen sosialisasi berlainan dan tidak selamanya sejalan satu sama lain. Apa ayng diajarkan keluarga mungkin saja berbeda dan bisa jadi bertentangan dengan apa yang diajarkan oleh agen sosialisasi lain. Misalnya, di sekolah anak-anak diajarkan untuk tidak merokok, meminum minman keras dan menggunakan obat-obatan terlarang (narkoba), tetapi mereka dengan leluasa mempelajarinya dari teman-teman sebaya atau media massa. Proses sosialisasi akan berjalan lancar apabila pesan-pesan yang disampaikan oleh agen-agen sosialisasi itu tidak bertentangan atau selayaknya saling mendukung satu sama lain. Akan tetapi, di masyarakat, sosialisasi dijalani oleh individu dalam situasi konflik pribadi karena dikacaukan oleh agen sosialisasi yang berlainan.

Menurut Fuller dan Jacobs (1973) dalam Sunarto (2004), yang termasuk ke dalam agenagen sosialisasi diantaranya adalah :

1) Keluarga; Keluarga merupakan institusi yang paling penting pengaruhnya terhadap proses sosialisasi. Hal ini dimungkinkan sebab berbagai kondisi keluarga. Pertama, keluarga merupakan kelompok primer yang selalu bertatap muka di antara anggotanya, sehingga dapat selalu mengikuti perkembangan anggota-anggotanya. Kedua, orang tua memiliki kondisi yang tinggi untuk mendidik anak-anaknya, sehingga menimbulkan hubungan emosional yang hubungan ini sangat memerlukan proses sosialisasi. Ketiga, adanya hubungan sosial yang tetap, maka dengan sendirinya orang tua memiliki peranan yang penting terhadap proses sosialisasi kepada anak (Sunarto, 2004).

Keluarga merupakan dimana anak akan diasuh dan dibesarkan yang berpengaruh besar terhadappertumbuhandan perkembangannya. Terutama keadaan ekonomi rumah tangga, serta tingkat kemampuan orang tua merawat juga sangat besar pengaruhnya terhadap pertumbuhan jasmani anak. Sementara itu tingkat pendidikan orang tua juga mempunyai pengaruh besar terhadap perkembangan rohaniah anak terutama kepribadian dan kemajuan pendidikannya (Dalyono, 2012). 
2) Kelompok Bermain; Kelompok bermain (sering juga disebut teman bermain) pertama kali didapatkan manusia ketika ia mampu berpergian ke luar rumah. Pada awalnya, teman bermain dimaksudkan sebagai kelompok yang bersifat rekreatif, namun dapat pula memberikan pengaruh dalam proses sosialisasi setelah keluarga. Puncak pengaruh teman bermain adalah pada masa remaja. Kelompok bermain lebih banyak berperan dalam membentuk kepribadian seorang individu.

3) Media Massa

a. Media Cetak; poster, leaflet, baligo, spanduk, umbul-umbul, $x$ banner, gimmick, koran, majalah dan tabloid.

b. Media Audio Visual; televisi, radio, film dan iklan.

c. Media Internet; jejaring sosial, website atau blog.

Metode yang digunakan dalam penelitian ini adalah metode deskriptif dengan data kualitatif, yaitu penelitian yang memaparkan situasi atau peristiwa atau penelitian observasional seperti yang dikemukakan oleh Wood (1997, dalam Rahmat, 2004:25).

Ciri lain dari metode deskriptif ialah titik berat pada obseravsi dan suasana alamiah (naturalistik setting). Penelitian ini juga bukan menjabarkan (analitis), tetapi juga memadukan (sintetis). Bukan saja melakukan klasifikasi, tetapi juga organisasi. Salah satu kegunaan lain dari penelitian deskriptif adalah penelitian ini sangat berguna dalam melahirkan atau menciptakan teori-teori tentatif. Barangkali disinilah letak perbedaan mendasar metode deskriptif kualitatif dibandingkan dengan metode lainnya. Metode deskriptif tidak menguji teori, melainkan mencari teori. Seringkali penelitian deskriptif timbul karena suatu peristiwa yang menarik perhatian peneliti, tetapi belum ada kerangka teoritis yang dapat menjelaskannya.

Peneliti deskriptif tidak jarang melahirkan apa yang disebut Seltiz, Wrightsman, dan Cook sebagi penelitian yang insightstimulating. Peneliti terjun ke lapangan tanpa dibebani atau diarahkan oleh teori. Ia tidak bermaksud menguji teori sehingga perspektif tidak tersaring. Peneliti bebas mengamati objek, menjelajah, dan menemukan wawasan-awasan baru sepanjang penelitian yang dialkukan. Penelitian tersebut nantinya akan terus menerus mengalami reformulasi dan redireksi ketika informasi-informasi baru ditemukan. Hipotesis tidak datang sebelum penelitian, melainkan baru akan muncul setelah penelitian berjalan. (Rakhmat, 2007:36)

Penelitian deskriptif memerlukan kualifikasi-kualifikasi yang memadai. Pertama, peneliti harus memiliki sifat reseptif. Ia harus selalu mencari, bukan menguji. Kedua, ia harus memiliki kekuatan integratif, kekuatan untuk memadukan berbagai macam informasi yang diterimanya menjadi satu keastuan penafsiran yang tepat. Jadi, penelitian deskriptif bukan saja menjabarkan, tetapi juga memadukan. Bukan saja klasifikasi, tetapi juga organisasi, maksudnya adalah data tersebut tidak hanya dipaparkan secara gamblang namun dipadukan disangkutpautkan dengan data lain yang berhubungan sehingga menjadi suatu temuan lapangan yang dapat menggambarkan secara jelas fenomena yang diteliti.

Penelitian ini dilaksanakan di Dinas Kesehatan Kabupaten Tasikmalaya. Subjek dalam penelitian ini adalah Pegawai Dinas Kesehatan Kabupaten Tasikmalaya yang terlibat dalam kegiatan sosialiasi, informan ini dipilih dikarenakan dalam penelitian ini mengkaji program sosialisasi yang dilakukan oleh bagian tersebut. Informan dalam penelitian ini terdiri dari informan pangkal dan informan pokok (key informan) (Koentjaraningrat, 1991 :130). Menurut Koentjaraningrat informan pangkal adalah orang yang dipandang mampu memberikan informasi secara umum dan mampu menunjuk orang lain sebagai informan pokok yang dapat memberikan informasi yang lebih mendalam. Informan pangkal dari penelitian ini adalah Kepala Dinas Kesehatan Pemerintah Kabupaten Tasikmalaya.

\section{HASIL DAN PEMBAHASAN}

Media yang digunakan dalam upaya sosialiasi kepada masyarakat tentang pentingnya imunisasi pasca isu vaksin mengandung Tripsin

Bulan Maret 2016 adalah Pekan Imunisasi Nasional (PIN) Polio (vaksin tripsin). Kampanye PIN Polio sudah dicanangkan pemerintah sejak 1 tahun sebelumnya yaitu 2015. Dari pemerintah secara nasional, sosialisasi kampanye PIN ini ditayangkan di berbagai media cetak dan 
elektronik, baik media massa maupun nirmassa (leaflet, brosur, pamflet, spanduk, dsb). Sedangkan di tingkat kabupaten, khususnya pemerintah Kabupaten Tasikmalaya, kampanye PIN Polio ini menjadi tanggung jawab Dinas Kesehatan bagian P2P, dan upaya-upayanya adalah:

1) Memberikan penjelasan mengenai proses pembentukan vaksin dengan menggunakan media tripsin kepada masyarakat dengan melakukan pertemuan antara MUI, Biofarma, Pemerintah kabupaten, dan tokoh masyarakat setiap kecamatan.

Dinkes mengundang berbagai nara sumber (Biofarma, MUI, tokoh-tokoh masyarakat daritingkatkecamatan, LSM/Ummu salamah, dll) melakukan diskusi. Dan menghasilkan pemetaan permasalahan, yaitu masing-masing pihak masih 'keukeuh' dengan sikapnya; Bio farma sudah menjelaskan bahwa tripsin hanya sebagai media tanam saja (jadi sampai saat ini, vaksin polio hanya bisa tumbuh di tanam pada tripsin akan tetapi tripsinnya sekarang bahkan sudah terbuat dari bahan sintesis, bukan asli pankreas babi); MUI menjelaskan bahwa karena selama memang belum ada media baru yang ditemukan maka karena sifatnya 'darurat' maka tidak apa-apa ; dan di kalangan tokoh masyarakat masih ada yang belum menerima keabsahan vaksin tersebut, yaitu dari Pager Ageung, Bantar Kalong dan Ummu Salamah. Dapat dikatakan bahwa hasil pertemuan yang dilakukan oleh Dinkes tidak menunjukkan titik temu karena tokoh masyarakat 'keukeuh' dengan asumsinya bahwa vaksin itu haram, Bio Farma 'keukeuh' bahwa tripsin itu sekedar media tanam saja, dan MUI keukeuh dengan fatwanya yaitu tidak menyatakan vaksin menjadi halal, tapi menyatakan selama pemerintah atau siapa pun belum bisa membuat vaksin yang terbebas dari tripsin maka vaksin diperbolehkan.

2) Melakukan pemetaan pendapat masyarakat mengenai vaksin di kabupaten Tasikmalaya.

Pemerintah Kabupaten Tasikmalaya menyelenggarakan pertemuan rutin setiap tahunnya dari tahun 2012, 2013 dan 2014 dengan tokoh tokoh di kecamatan, tokoh agama, MUI dan LSM. Ada dua daerah yang sulit untuk menerima informasi bahwa vaksin itu dibolehkan yaitu kecamatan Pager Ageung dan kecamatan Bantar Kalong. Tetapi pada akhirnya, satu keluarga dua keluarga sudah mulai bisa masuk/cair, walau pun hanya untuk vaksin tertentu seperti BCG, DPT, campak, pentagio. Polionya tetap di anggap haram, dan masyarakat mulai menanyakan/memilah vaksin mana yang haram dan mana yang tidak. Masyarakat sudah mulai melakukan pemilahan, berdasarkan pengetahuan mereka tapi di wilayah kecamatan Pager Ageung dan kecamatan Bantar Kalong, kelompok pengajiannya tetap menganggap semua vaksin haram. Jadi hasil pertemuan itu hanya sedikit sekali pengaruhnya, karena ini menyangkut masalah keyakinan, maka tidak bisa dipaksakan.

3) Melakukan roadshow ke 40 puskesmas di Kabupaten Tasikmalaya, melakukan pertemuan dengan 351 bidan, selain itu Dinkes juga melakukan pertemuan lintas sektor dengan 39 camat, pihak kepolisian, Koramil, Kodim, termasuk Kejaksaan, Kemenag, PKK, dinas pendidikan kasie Paud.

4) Upaya-upaya yang dilakukan oleh dinas kesehatan dalam melakukan sosialiasi mengenai pentingnya imunisasi dan pengetahuan mengenai tripsin dalam vaksin kepada masyarakat melalui media massa dan nirmassa, iklan, talkshow di radio, memanfaatkan media cetak dan media luar ruang yang diharapkan dapat merubah persepsi masyarakat mengenai vaksin terutama masyarakat yang menolak dengan alasan keyakinan atau agama.

Manusia tidak dapat mengadakan sosialisasi tanpa melibatkan pihak atau unsur dari luar. Unsur dari luar itulah yang disebut media sosialisasi. Media sosialisasi adalah pihak-pihak yang menjadi perantara terjadinya sosialisasi. (Suhardi dan Sunarti, 2009).

Dalam bukunya yang berjudul dinamika komunikasi, Onong Ucjana Effendy (2002:10), menuturkan sosialisasi menggunakan media dapat diklasifikasikan menjadi media massa dan media nirmassa. Media massa dapat digunakan apabila komunikan berjumlah banyak atau bertempattinggal jauh. Media massayang banyak digunkan adalah surat kabar, radio, televisi. Keuntungan komunikasi dengan menggunakan 
media massa adalah media massa menimbulkan keserempakan, artinya suatu pesan dapat diterima oleh komunikan yang jumlahnya relatif banyak, ratusan ribu, jutaan, bahkan ratusan jutaan pada saat yang sama secara bersama-sama. Sedangkan media nirmassa umumnya digunakan dalam komuni-kasi untuk orang-orang atau kelompokkelompok tertentu. Surat, telepon, spanduk, pamflet, brosur, kaset, video, dan lain-lain adalah media nirmassa karena tidak memiliki daya keserempakan dan komunikannya tidak bersifat massal.

Senada dengan yang dikatakan oleh Fuller dan Jacobs (1973) dalam Sunarto (2004), yaitu kelompok media massa terbagi menjadi 3 bagian yaitu media cetak (surat kabar, majalah, tabloid), media audio visual (radio, televisi, video, film, iklan), dan media internet. Besarnya pengaruh media sangat tergantung pada kualitas dan frekuensi pesan yang disampaikan.

Jenis media yang digunakan pada sosialisasi PIN Polio oleh dinas kesehatan Kabupaten Tasimlaya adalah; secara nasional dari pemerintah melalui media massa (televisi, radio), media sosial (twitter, facebook), serta media nir-massa (spanduk, pamflet, baligo, brosur, CD). Secara khususnya Pemkab. Tasikmalaya untuk media massanya melalui radio swasta (2 radio swasta yang ada di kota tasikmalaya yaitu Talk show), media nir-massa (spanduk, baligo, umbul-umbul, balon, kaos), serta media sosial (twitter, WA, bbm).

Pihak dinas kesehatan menggunakan media massa sebagai salah satu media sosialisasinya karena media massa sangat efektif dalam menyampaikan pesan kepada khalayak banyak dalam waktu singkat dan serentak. Media massa merupakan salah satu alat dalam proses komunikasi massa, karena media massa mampu menjangkau khalayak yang lebih luas dan relatif lebih banyak, heterogen, anonim, pesannya bersifat abstrak dan terpencar. Media massa sendiri dalam kajian komunikasi massa sering dipahami sebagai perangkat-perangkat yang diorganisir untuk berkomunikasi secara terbuka dan pada situasi yang berjarak kepada khalayak luas dalam waktu yang relatif singkat (McQuail, 2000:17). Media massa adalah media komunikasi dan informasi yang melakukan penyebaran informasi secara massa dan dapat diakses oleh masyarakat secara massal (Bungin, 2006:7).
Dinkes Kabupaten Tasikmalaya mengemukakan alasan pemilihan media massa tersebut yaitu karena untuk efisiensi dalam arti memang itu yang terjangkau secara financial, tetapi efektif karena dapat menjangkau dan menyebarluaskan informasi kepada masyarkat luas di kabupaten tasikmalaya.

Senada dengan yang dikatakan Nurudin yaitu media massa diyakini mempunyai kekuatan yang dahsyat untuk mempengaruhi sikap dan perilaku masyarakat. Bahkan media massa bisa mengarahkan masyarakat seperti apa yang akan dibentuk di masa yang akan datang. Media massa mampu mengarahkan, membimbing dan mempengaruhi kehidupan di masa kini dan masa mendatang (Nurudin, "Media Massa dan Humanisasi" dalam Stefanus Tri Guntur Narwaya, et.al, 2005, "Komunikasi, Perubahan Sosial dan Dehumanisasi, hlm. 59).

Pihak dinas kesehatan mengangap sosialisasi PIN (Pekan Imunisasi Nasional) dengan menggunakan media massa dan nir massa sudah cukup efektif dengan indikator keberhasilan sebagai berikut:

1. Dapat menjangkau ke seluruh warga masyarakat yang tersebar di 39 kecamatan Kab. Tasikmalaya

2. Jelas informasinya, karena pada media sosial WA dan BBM bisa dilakukan dialog/ tanya jawab.

3. Dapat menarik perhatian, misalnya pemasangan umbul-umbul, baligo, spanduk serta hiasan balon-balon PIN menghiasi tempat pelaksanaan PIN.

Media massa dalam masyarakat informasi, memiliki peranan yang sangat penting. Perubahan kebijakan politik, social, ekonomi dan pertahanan keamanan di banyak negara, menarik perhatian masyarakat informasi. Peristiwa keseharian sampai yang memiliki dampak terhadap perubahan arah hidup masyarakat dunia baik langsung dan tidak langsung terungkap melalui media massa, cetak dan elektronik. Perkembangan teknologi, memungkinkan infor-masi dari belahan dunia lain sekali pun dapat diterima dalam pangkuan khalayak dengan seketika. Informasi untuk memperluas wawasan sampai pada mengedukasi masyarakat, menjadi "santapan" keseharian masyarakat informasi. (Wardhani 2008:20). Selain itu, media massa mempunyai peranan penting dalam penyebaran 
informasi/berita kepada masyarakat juga kepada pemerintah dan dalam pembentukan pendapat umum (Rachmadi 1992:54)

Dalam kegiatan sosialisasi ini pihak dinkes menggunakan dua jenis media yaitu media massa dan media nirmassa, hal ini bertujuan agar pesan yang disampaikannya dapat efektif dalam menjangkau masyarakat luas di kabupaten Tasikmalaya. Senada dengan yang dikemukakan Onong Uchjana Effendy (2002:37), untuk mencapai sasaran komunikasi kita dapat memilih salah satu atau gabungan dari beberapa media, bergantung pada tujuan yang akan dicapai, pesan yang akan disampaikan, dan teknik yang akan dipergunakan, Mana yang terbaik dari sekian banyak media komunikasi itu tidak dapat ditegaskan sebab masing-masing memiliki kelebihan dan kekurangan.

\section{Hambatan dan Evaluasi yang di hadapai Dinas Kesehatan Kabupaten Tasikmalaya dalam upaya sosiliasi kepada masyarakat tentang pentingnya imunisasi pasca isu vaksin mengandung Tripsin}

Nasution (1999:127-128) menyebutkan bahwa dalam proses sosialisasi tidak selalu berjalan lancar karena adanya sejumlah kendala, yaitu:

a) Kesulitan komunikasi: Komunikasi merupakan suatu proses interaksi dengan suatu stimulus (rangsangan) yang memperoleh suatu arti tertentu dijawab oleh orang lain (respon) secara lisan, tertulis maupun dengan aba-aba (Susanto, 1983:15). Kesulitan komunikasi dalam proses sosialisasi yaitu terjadi bila anak tidak mengerti apa yang diharapkan darinya atau tidak tahu apa yang diinginkan oleh masyarakat atau tuntutan kebudayaan tentang kelakuannya.

b) Adanya pola kelakuan yang berbeda-beda atau yang bertentangan.

c) Perubahan-perubahan yang terjadi dalam masyarakat sebagai akibat modernisasi, industrialisasi, dan urbanisasi.

Hambatan-hambatan yang dihadapi Dinkes Kab. Tasikmalaya dalam sosialisasi dan pelaksanaan PIN polio 2016 :

a) Biaya sosialisasi dan pelaksanaan Program Imunisasi Nasional (PIN) Polio ini adalah dari APBN, APBD melalui BOK (bantuan operasional kesehatan) th 2016. Akan tetapi karena pelaksanaan PIN 2016 ini jatuh di bulan Maret, anggaran dana tersebut belum 'turun', oleh karena itu semua dana adalah dana talangan dan utang.

b) Terbatasnya petugas Dinkes (hanya terdiri Kasie P2P, 1 staf yaitu pengelola cold chain, kasie program dan dibantu 1 petugas administrasi)

c) Kondisi ada lokasi masyarakat jauh dan susah dijangkau kendaraan bermotor, sehingga pada pelaksanaan PIN memakan waktu 3 hari dan ada yang dilaksankan sore hari.

d) Tempat membawa vaksin (termos vaksin) standar internasional yang dimiliki Dinkes danPuskesmaskurangjumlahnya, sementara harganya mahal dan anggaran belum turun. Jadi sebagian tempat membawa vaksinnya adalah termos es biasa (tidak standar)

e) Terlambatnya honor para petugas puskesmas, para Kader.

Menurut Gunawan (2000:48), dalam proses sosialisasi bisa terjadi kendala atau hambatan, hal ini karena:

1) Terjadinya kesulitan komunikasi; Kesulitan komunikasi terjadi karena yang berkomunikasi adalah manusia dengan segala perbedaannya. Faktor-faktor yang mempengaruhi komunikasi dalam keluarga yaitu: citra diri dan citra orang lain, suasana psikologis, lingkungan fisik, kepemimpinan, bahasa, dan perbedaan usia. Citra diri yaitu ketika orang berhubungan dan berkomunikasi dengan orang lain, dia merasa dirinya sebagai apa dan bagaimana. Suasana psikologis mempengaruhi komunikasi, komunikasi sulit berlangsung jika seseorang dalam keadaan marah, kecewa, bingung, diliputi prasangka, dan suasana psikologis lainnya. Lingkungan fisik juga mempengaruhi komunikasi, karena komunikasi dapat berlangsung di mana saja dan kapan saja dengan gaya dan cara yang berbeda. Selain itu cara kepemimpinan (otoriter, demokratis, laissez faire), penggunaan bahasa, dan perbedaan usia juga mempengaruhi proses komunikasi.

2) Adanya pola kelakuan yang berbeda-beda atau bertentangan; Pola kelakuan berbedabeda atau bertentangan yang diperoleh anak dapat mempengaruhi proses sosialisasi. Anak akan merasa bingung dengan perbedaan tersebut. 
Pendapat para ahli di atas pada dasarnya sama, yaitu menyatakan bahwa kendala dalam proses sosialisasi meliputi adanya kesulitan komunikasi, pola kelakuan yang berbeda, dan akibat perubahan dalam masyarakat. Proses sosialisasi selain memiliki kendala juga memiliki pendukung. Gunawan (2000:49) menyatakan bahwa sosialisasi yang sukses bila disertai dengan toleransi yang tulus, disiplin dan patuh terhadap norma-norma masyarakat, hormat-menghormati, dan harga-menghargai. Dengan pendukung tersebut, proses sosialisasi dapat berjalan dengan baik.

Melakukan komunikasi yang efektif tidaklah mudah. Beberapa ahli menyatakan bahwa tidak ada proses komunikasi yang sebenar-benarnya efektif, karena selalu terdapat hambatan. (Effendy, 2003:45) menyatakan bahwa hambatan komunikasi meliputi :

1) Gangguan (Noises), terdiri dari gangguan mekanik dan gangguan semantik. Gangguan mekanik adalah gangguan yang disebabkann saluran komunikasi atau kegaduhan yang bersifat fisik. Seperti gangguan suara pada pesawat radio. Sedangkan gangguan semantik adalah gangguan yang disebakan oleh perubahan kata-kata.

2) Prasangka (Prejudice), Sikap seseorang terhadap sesuatu secara umum selalu terdapat dua alternatif like and dislike, atau pun simpati dan tidak simpati. Dalam sikap negatif (dislike juga tidak simpati) termasuk prasangka yang akan melahirkan curiga dan menentang komunikasi. Dalam prasangka emosi memaksa seseorang untuk menarik kesimpulan atas dasar stereotif (tanpa menggunakan pikiran rasional). Emosi sering membutakan pikiran dan pandangan terhadap fakta yang nyata, tidak akan berpikir secara objektif dan segala yang dilihat selalu akan dinilai negatif.

Proses evaluasi sosialisasi sepaket dengan pelaksanaan PIN dilakukan Dinkes Kab. Tasikmalaya yaitu sebagai berikut:

1. Memantau para petugas lapangan dengan cara langsung melihat ke TKP, dan menerima laporan secara harian dari para petugas pada saat pelaksanaan program (yaitu dari tanggal 9-14 Maret 2016), tentang jumlah bayi/ anak yang divaksin, dan vaksin yang sudah dipakai (apabila ada kekurangan langsung
Dinkes mendrop vaksin tersebut). Laporan langsung disampaikan petugas melalui media sms, WA, BBM dan e-mail ke Dinkes)

2. Di bantu para aparat desa, tokoh masyarakat, Babinsa/Babinmas, melakukan swipping di tanggal 12, 13, 14 Maret 2016, dan ternyata masih ada bayi dan anak yang masih belum divaksin di tgl pelaksanaan yaitu 9 dan 11 Maret 2016.

3. Merekap dan kemudian melaporkan hasil resmi pencapaian PIN polio ke tingkat propinsi. Data menunjukkan sebagai berikut:

a. Cakupan Sasaran: -a.proyeksi=149.904; b. Pendataan akhir $($ Riil $)=145.327$

b. Hasil/pencapaian $=144.049$

c. Persentase; a. Proyeksi $=96,09 \%$; b. Hasil pendataan akhir (riil) $=99,12 \%$

d. Belum imunisasi : a. Menolak $=126$; b. Keluar kota $=663$; c. Sakit $=481$; d. Meninggal $=1$; e. BBLR $=1$

Hasil evaluasi pelaksanaan PIN polio 2016 di Kabupaten Tasikmalaya, berjalan lancar dan baik, meskipun ada hambatan namun dapat diatasi sehingga tidak mempengaruhi pelaksanaan PIN, bahkan dapat dikatakan berhasil (data capaian proyeksi menunjukkan angka lebih). Pada masyarakat (di desa Pager Ageung, dan desa Bantar Kalong) yang awalnya sikapnya negatif, pada saat pelaksanaan melebur/cair dan tidak mengadakan aksi-aksi provokatif bahkan ada juga yang anaknya di imunisasi.

Menurut informan, keberhasilan PIN polio ini karena sosialisasi kampanye dari media massa menjangkau masyarakat secara luas dan informasinya jelas sehingga masyarakat sadar betul akan pentingnya memberikan imunisasi, khususnya polio umumnya imunisasi dasar kepada anak-anaknya.

Beberapa waktu yang lalu, dunia kesehatan gempar oleh berita mengani vaksin palsu, banyak masyarakat yang tidak percaya vaksin palsu bisa menyebar di kalangan tenaga kesehatan. Hal ini sedikit banyak dapat mempengaruhi kegiatan sosialiasi mengebai PIN yang dialkukan oleh dinas kesehatan. Tetapi menurut informan berita mengenai vaksin palsu tersebut tidak berpengaruh terhadap kepercayaan masyakat kepada dinas kesehatan.

Sampai saat ini kasus vaksin palsu tidak mempengaruhi masyarakat untuk melakukan imunisasi pada anaknya.Terbukti rutinitas 
pelayanan pos yandu tidak turun, bahkan ada orang tua yang tadinya melakukan imunisasi dasar di klinik swasta dan dokter pribadi, beralih ke puskesmas dan pos yandu. Mereka (masyarakat) mengetahui bahwa vaksin palsu itu hanya ada di poliklinik atau rumah sakit swasta, di praktrek dokter anak karena vaksin palsu itu jalur mendistribusiannya melalui distributor tidak resmi.

\section{SIMPULAN}

1) Media yang digunakan dalam upaya sosialiasi kepada masyarakat tentang pentingnya imunisasi pasca isu vaksin mengandung Tripsin yaitu secara nasional dari pemerintah melalui media massa (televisi, radio), media sosial (twitter, facebook), serta media nirmassa (spanduk, pamflet, baligo, brosur, CD). Secara khususnya Pemkab. Tasikmalaya untuk media massanya melalui radio swasta (2 radio swasta yang ada di kota tasikmalaya yaitu Talk show), media nir-massa (spanduk, baligo, umbul-umbul, balon, kaos), serta media sosial (twitter, WA, bbm).

2) Hambatan-hambatan yang dihadapi Dinkes Kab. Tasikmalaya dalam sosialisasi dan pelaksanaan PIN polio 2016 : a) Biaya sosialisasi dan pelaksanaan Program Imunisasi Nasional (PIN) Polio ini adalah dari APBN, APBD melalui BOK (bantuan operasional kesehatan) th 2016. Akan tetapi karena pelaksanaan PIN 2016 ini jatuh di bulan Maret, anggaran dana tersebut belum 'turun', oleh karena itu semua dana adalah dana talangan dan utang; b) Terbatasnya petugas Dinkes (hanya terdiri Kasie P2P, 1 staf yaitu pengelola cold chain, kasie program dan dibantu 1 petugas administrasi); c) Kondisi ada lokasi masyarakat jauh dan susah dijangkau kendaraan bermotor, sehingga pada pelaksanaan PIN memakan waktu 3 hari dan ada yang dilaksankan sore hari; d) Tempat membawa vaksin (termos vaksin) standar internasional yang dimiliki Dinkes dan Puskesmas kurang jumlahnya, sementara harganya mahal dan anggaran belum turun. Jadi sebagian tempat membawa vaksinnya adalah termos es biasa (tidak standar)

\section{Saran}

Dari pemaparan kesimpulan diatas dan telah dilakukan penelitian, ada beberapa saran untuk Dinas Kesehatan Tasikmalaya dalam merumuskan program komunikasi yang akan digunakan dalam sosialisasi Pekan Imunisasi Nasional yaitu:

1) Peran masyarakat dan peran LSM perlu di tingkatkan lagi dengan jalan bekerja sama dengan pemerintah dalam mensukseskan Pekan Imunisasi Nasional tahun 2017.

2) Perlu dilakukan penelitian lebih lanjut mengenai efektifitas penggunaan media massa dan nirmassa saat ini yang telah dilakukan oleh dinas kesehatan, agar dapat menyusun sebah model sosialisasi yang tepat menggunakan media massa atau new media.

\section{DAFTAR PUSTAKA}

Bungin, Burhan. 2006. Sosiologi Komunikasi. Jakarta: Kencana Prenada Media Group.

DEPKES. 2010. Profil Kesehatan Indonesia 2010. Jakarta. Kementrian Kesehatan Indonesia.

Effendi, Onong Uchjana. 2003. Ilmu, Teori dan Filsafat Komunikasi. Bandung: PT. Citra Aditya Bhakti

Effendy, Onong Uchjana.2002. Dinamika Komunikasi.Bandung : Rosda karya

Gunawan, Ary H. 2000. Sosiolosi Pendidikan. Jakarta: Rineka Cipta.

McQuail, Denis. 2000. Teori Komunikasi Massa. Jakarta: Erlangga.

Moeleong, Lexy. 2006. Penelitian Kualitatif. Bandung: Remaja Rosda Karya.

Muhadjir, Noeng. 1996. Metode Penelitian Kualitatif. Yogyakarta: Rakesarasin. Nazir, Moh., Ph.D. 1983. Metode Penelitian. Jakarta: Ghalia Indonesia

Narwoko, J Dwi dan Bagong Suyanto 2006. Sosiologi: Teks Pengantar dan Terapan. Jakarta : Kencana

Putri Dwiastuti, Nanang Prayitno; FaktorFaktor Yang Berhubungan Dengan 
Pemberian Imunisasi BCG Di Wilayah Puskesmas UPT Cimanggis Kota Depok Tahun 2012, Jurnal Ilmiah Kesehatan, 5(1); Januari 2013

Rachmadi, F. 1992. Public Relations Dalam Teori dan Praktek, Aplikasi Dalam Badan Usaha Swasta dan Lembaga Pemerintah. Jakarta : PT Gramedia Pustaka Utama.

Ranuh dkk. 2011. Buku Imunisasi di Indonesia. Jakarta : Satgas Imunisasi IDAI.

Rakhmat, Jalaluddin. 2004. Metode Penelitian Komunikasi. Bandung: Remaja Rosdakarya.
Ruslan, Rosady.1997. Kiat dan Strategi Kampanye Public Relations. Grafindo. Jakarta

Suhardi \& Sunarti S. (2009). Sosiologi 2. Bandung: Pusat Perbukuan Departemen Pendidikan Nasional

Susanto, Phil Astrid S. 1983. Pengantar Sosiologi dan Perubahan Sosial. Bina Cipta.

Stefanus Tri Guntur Narwaya, et al,. 2005. Komunikasi, Perubahan Sosial dan Dehumanisasi. Surakarta: Pustaka Rumpun Ilalang

Sunarto, K. 2004. Pengantar Sosiologi. Edisi Revisi. Jakarta : FEUI 